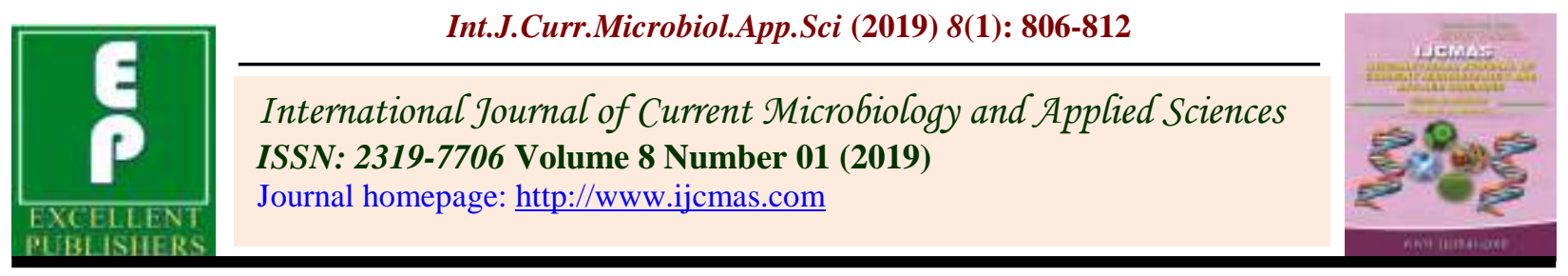

Original Research Article

https://doi.org/10.20546/ijcmas.2019.801.088

\title{
Influence of Weather Parameters on Pest of Okra in Parbhani Kranti Variety
}

\author{
D.D. Burade*, A.M. Khobragade and P.B. Shinde \\ Department of Agricultural Meteorology, College of Agriculture, Vasantrao Naik \\ Marathwada Krishi Vidyapeeth, Parbhani- 431402 (MS), India \\ *Corresponding author
}

\section{A B S T R A C T}

\begin{tabular}{|l|}
\hline K e y w or d s \\
Weather \\
parameters, \\
Pest, \\
Okra \\
\hline Article Info \\
\hline $\begin{array}{l}\text { Accepted: } \\
\text { 07 December } 2018 \\
\text { Available Online: } \\
\text { 10 January } 2019\end{array}$ \\
\hline
\end{tabular}

\section{Introduction}

Okra (Abelmoschus esculentus L.) is a warm season annual crop of the family malvaceae originated in South Africa and is one of the most common and popular vegetable grown in tropical and subtropical regions in India. It is cultivated throughout the year except one or two cold months due to favorable climatic conditions for its cultivation. Okra is cultivated particularly in states of Uttar Pradesh, Madhya Pradesh, Karnataka and Maharashtra. In India, it is grown in almost all parts, mainly in rainy and summer season. In 2011-12 total area under okra in India was
The study on influence of weather parameters on pest of okra in Parbhani Kranti variety showed that the peak period of incidence of Earias vitella was observed during $15^{\text {th }} \mathrm{MW}$ (45 per cent), whitefly was during $21^{\text {st }}$ MW (25 whiteflies / 3 leaves) and Jassid was observed during $21^{\text {st }} \mathrm{MW}$ (20 Jassids / 3 leaves). The correlation of Earias vitella with weather parameters maximum and minimum temperature, evaporation and wind velocity was positively significant and morning and evening relative humidity was negatively The The correlation of whitefly with weather parameters maximum and minimum temperature and evaporation was positively significant and morning and evening relative humidity was negatively significant but bright sunshine hours was non significant. The correlation of jassid with weather parameters maximum and minimum temperature, evaporation and wind velocity was positively significant and morning relative humidity negatively significant but bright sunshine hours and rainfall were non significant.

432.00 thousand hectares with annual production of 4528 MT in Maharashtra. It is cultivated on an area of 27.30 thousand hectares with annual production of 175.5 thousand tones (Anonymous, 2011).

The meteorological parameters play an important role in deciding the success or failure of the crop, because these factors strongly influence the physiological expression of genetic potential of the crops. It is well known that yield from any given crop or variety depends on the availability of certain optimum condition of solar radiation, temperature, heat units, soil moisture, relative 
humidity etc. during different stages of crop growth.

The pest problem in okra is more or less similar to that of cotton crop. It is usually attacked by sucking pests right from the early seedling stage to last fruit harvest. The losses in the yield of okra by fruit borer were 69.0 per cent (Rawat and Sahu, 1973) reported that losses in okra due to leaf hopper and fruit borer were 50 to 52 and 49 to 74 percent respectively. The losses in fruit yield of okra by Earias spp. Were Found to be lowest (22.79 percent) in crop sown in July and maximum (50.58 per cent) in crop sown in may (Brar et al., 1994). The maximum damage by Earias spp. to the fruit and buds of okra was reported to be 67.7 and 52.2 per cent in the late October and 54.04 percent net yield loss of okra due to pest in summer (Krishnaih, 1980). Hence study on Influence of Weather Parameters on Pest of Okra in Parbhani kranti variety was undertaken which would give an idea about peak period of their activity and may be helpful in developing pest management strategy.

\section{Materials and Methods}

The investigation was carried out during summer season 2011-2012, on the experimental farm, Department of Horticulture, Vasantrao Naik Marathwada Krishi Vidyapeeth, Parbhani, $\left(19^{\circ} 16^{\prime} \mathrm{N}\right.$ latitude, $76^{\circ} 47^{\prime} \mathrm{E}$ longitude and $409 \mathrm{~m} \mathrm{MSL}$ ) with an objectives to find out influence of weather parameters on pest of okra. The experiment was conducted under unprotected condition which was non replicated. Observations were recorded on population counts of Earias vitella, Whitefly and jassids from sowing to harvest at weekly interval with five randomly selected plants without employing any plant protection measure. The different weather parameters recorded were collected from central agromet observatory located at VNMKV, Parbhani. Simple correlation and regression of weather parameters viz., rainfall (RF), rainy days (RD), maximum and minimum temperature $\left(T_{\max }\right.$ and $\mathrm{T}_{\mathrm{min}}$ ), relative humidity during morning and evening (RH-I and RH-II), Evaporation (EVP), bright sunshine hours (BSS) and wind velocity (WV) with Earias vitella, Whitefly and jassids was worked out.

\section{Results and Discussion}

\section{Population dynamics of Earias vitella}

The data on population dynamics of Earias vitella (Table 1) revealed that the incidence of pest was observed in $10^{\text {th }} \mathrm{MW}$ of the year. The range of attack was $0-45$ per cent and the meteorological condition at this time were $\mathrm{RF}$ (0.0), $\mathrm{T}_{\max }\left(37.0{ }^{\circ} \mathrm{C}\right), \mathrm{T}_{\min }\left(17.2{ }^{0} \mathrm{C}\right)$, relative humidity (RH-I 71 and RH-II 20 per cent). The highest incidence was recorded in $15^{\text {th }}$ MW (45 per cent) when crop was up to 52-55 days and meteorological conditions were RD (01), $\mathrm{T}_{\max }\left(38.4^{0} \mathrm{C}\right), \mathrm{T}_{\min }\left(23.3^{0} \mathrm{C}\right)$, relative humidity (RH-I 63 and RH-II 23 per cent). These findings are in argument with Dhamdhere et al (1985) and Balsubramimyn et al (1982) who also reported that the damage by Earias vitella increased correspondingly with advancing crop stage and that the maximum damage was found around the mean temperature of $30^{\circ} \mathrm{C}$ with lower humidity.

\section{Population dynamics of whiteflies}

The data on population dynamics of whiteflies (Table 1) revealed that the incidence of pest observed from sowing to harvesting period. The incidence of whiteflies observed in $10^{\text {th }}$ MW in which the weather parameters were RF $(0.0 \mathrm{~mm}) \mathrm{T}_{\max }\left(37.0{ }^{0} \mathrm{C}\right), \mathrm{T}_{\min }\left(17.2{ }^{0} \mathrm{C}\right)$, relative humidity (RH-I 71 and RH-II 20 per cent) The maximum incidence was recording at $21^{\text {st }}$ MW i.e., 25 whiteflies / 3 leaves at this time weather parameters were $\mathrm{RF}(0.7 \mathrm{~mm}), \mathrm{T}$ 
$\max \left(40.7{ }^{0} \mathrm{C}\right), \mathrm{T}_{\min }\left(27.0^{\circ} \mathrm{C}\right)$, relative humidity (RH-I 55 and RH-II 24 per cent) and BSS (10.6 hrs). The present finding regarding peak incidence of whitefly are discussed here with those reported earlier by Daware et al 2003 that the first appearance of whitefly from first week of August $\left(31^{\text {st }} \mathrm{MW}\right)$ and peak in first week of October to second week of November $\left(40^{\text {th }}\right.$ to $\left.46^{\text {th }} \mathrm{MW}\right)$. Mohapatra (2008) reported that the peak population of $B$. tabaci attained during $44^{\text {th }} \mathrm{MW}$ (Oct. 29 to Nov. 04).

\section{Population dynamics of jassid}

The data on population dynamic of jassid is presented in Table 1 revealed that the incidence of pest was observed from sowing to the harvesting period. The incidence of pest observed in $9^{\text {th }}$ MW ( 2 jassids $/ 3$ leaves) when weather parameters were RF $(0.0 \mathrm{~mm}), \mathrm{T}_{\max }$ $\left(33.1^{0} \mathrm{C}\right), \mathrm{T}_{\min }\left(17.5^{\circ} \mathrm{C}\right)$, Humidity (RH I 74, RH II 34 per cent) and BSS (9.0 hrs). The highest incidence of jassid was in the MW $21^{\text {st }}$ when $\mathrm{RF}(0.7 \mathrm{~mm}), \mathrm{T}_{\max }\left(40.7^{0} \mathrm{C}\right), \mathrm{T}_{\text {min }}$ $\left(27.0^{\circ} \mathrm{C}\right)$, relative humidity (RH-I 55 and RHII 24 per cent) and BSS (10.6 hrs) The present findings are in agreement with Hedge et al, (2004) noticed the incidence of jassid during $2^{\text {nd }}$ fortnight of August and peaked during the first fortnight of September and declined later.

\section{Simple correlation and regression between weather parameters and Earias vitella on okra}

The data (Table 2) showed that the correlation of Earias vitella with weather parameters $\mathrm{T}_{\max }$ $\left(\mathrm{r}=0.753^{* *}\right), \mathrm{T}_{\min }\left(\mathrm{r}=0.689^{* *}\right), \operatorname{EVP}(\mathrm{r}=$ $0.707 * *), \mathrm{WV}\left(\mathrm{r}=0.543^{*}\right)$ were positively significant and relative humidity RH-I and RH-II were negatively significant but RF and BSS were non significant.

The simple regression was worked out between weather parameters and incidence of Earias vitella with regression coefficient (b) and constant (a). The regression equations were $\mathrm{Y}=77.60-0.9194 \mathrm{x}, \mathrm{Y}=45.55-1.060 \mathrm{x}$ which indicated that for every unit increase in RH-I and RH-II decrease Earias vitella by 0.9194 and 1.060 respectively. Also $\mathrm{Y}=$ $11.51+3.594 x, Y=-24.69+2.260 x, Y=-$ $19.88+4.564 \mathrm{x}, \mathrm{Y}=-6.851+5.384 \mathrm{x}$ which indicated that every unit increase in $\mathrm{T}_{\max }, \mathrm{T}_{\min }$, EVP and WV increased Earias vitella by $3.594,2.260,4.564$ and 5.384 respectively. Similar results were observed by Gupta et al., (1998).

\section{Simple correlation and regression between weather parameters and whitefly on okra}

The data presented in Table 2 showed that correlation of whiteflies population on okra with weather parameters, $\mathrm{T}_{\max }(\mathrm{r}=0.880 * *)$, $\mathrm{T}_{\min }(\mathrm{r}=0.634 * *), \operatorname{EVP}(\mathrm{r}=0.847 * *), \mathrm{WV}(\mathrm{r}$ $\left.=0.579^{*}\right)$ was positive and significant. Relative humidity RH-I ( $\mathrm{r}=-0.767 * *)$ and RH-II ( $\left.\mathrm{r}=-0.695^{* *}\right)$ were negatively significant. The association of whitefly population with RF and BSS was positive non significant.

The simple regression was worked out between weather parameters and incidence of whitefly population along with the regression coefficient (b) and constant (a) their equation were set up. The regression equation were $\mathrm{Y}=$ $52.45-0.6167 x, \quad \mathrm{Y}=34.32-0.8684 \mathrm{x}$ which indicated that for every unit increase in relative humidity $\mathrm{RH}-\mathrm{I}$ and $\mathrm{RH}-\mathrm{II}$ decreased whitefly by 0.6167 and 0.8684 , respectively. Also $\mathrm{Y}=-79.17+2.472 \mathrm{x}, \mathrm{Y}=-10.03+$ $1.225 \mathrm{x}, \mathrm{Y}=-14.42+3.219 \mathrm{x}, \mathrm{Y}=-2.930+$ $3.381 \mathrm{x}$ which indicated that every unit decrease in $\mathrm{T}_{\max }, \mathrm{T}_{\min }, \mathrm{EVP}$ and $\mathrm{WV}$ decreased by $2.472,1.225,3.219,3.381$ respectively. Similar results were observed by Dhaka et al., (2008), they reported that the $\mathrm{T}_{\max }$ had positive significant and $\mathrm{RH}-\mathrm{II}$ was negative significant effect on whitefly population. 
Table.1 Seasonal abundance of Earias vitella, whitefly and jassid on Okra

\begin{tabular}{|c|c|c|c|c|c|c|c|c|c|c|c|c|}
\hline \multirow[t]{2}{*}{ MW } & \multirow[t]{2}{*}{$\begin{array}{c}\text { Rainfall } \\
\text { (mm) }\end{array}$} & \multirow[t]{2}{*}{$\begin{array}{c}\text { Rainy } \\
\text { day }\end{array}$} & \multicolumn{2}{|c|}{$\begin{array}{c}\text { Temperature } \\
\left({ }^{\circ} \mathrm{C}\right)\end{array}$} & \multicolumn{2}{|c|}{$\begin{array}{c}\text { Humidity } \\
(\%)\end{array}$} & \multirow[t]{2}{*}{$\begin{array}{l}\text { EVP } \\
(\mathrm{mm})\end{array}$} & \multirow[t]{2}{*}{$\begin{array}{l}\text { BSS } \\
\text { (hrs) }\end{array}$} & \multirow[t]{2}{*}{$\begin{array}{c}\text { W. V. } \\
\text { (Kmph) }\end{array}$} & \multirow{2}{*}{$\begin{array}{c}\text { Damage by } \\
\text { Earias } \\
\text { Vitella }(\%)\end{array}$} & \multirow{2}{*}{$\begin{array}{c}\text { No of White } \\
\text { Flies } \\
\text { /3 leaves }\end{array}$} & \multirow{2}{*}{$\begin{array}{c}\text { No of } \\
\text { Jassids } \\
\text { /3 leaves }\end{array}$} \\
\hline & & & Max. & Min. & RH-I & RH-II & & & & & & \\
\hline 8 & 0.0 & 0.0 & 31.6 & 15.7 & 72 & 36 & 5.9 & 9.2 & 4.7 & 00 & 00 & 00 \\
\hline 9 & 0.0 & 0.0 & 33.1 & 17.5 & 74 & 34 & 6.0 & 9.0 & 4.1 & 00 & 00 & 02 \\
\hline 10 & 0.0 & 0.0 & 37.0 & 17.2 & 71 & 20 & 7.6 & 10.5 & 3.7 & 05 & 06 & 04 \\
\hline 11 & 0.0 & 0.0 & 36.5 & 14.0 & 69 & 19 & 7.5 & 11.0 & 4.3 & 08 & 14 & 05 \\
\hline 12 & 1.0 & 0.0 & 38.2 & 18.6 & 47 & 14 & 8.4 & 10.7 & 4.2 & 20 & 21 & 06 \\
\hline 13 & 0.7 & 0.0 & 38.5 & 17.1 & 69 & 13 & 8.4 & 10.7 & 4.4 & 22 & 20 & 07 \\
\hline 14 & 0.0 & 0.0 & 38.1 & 19.8 & 54 & 17 & 9.3 & 10.8 & 6.3 & 40 & 16 & 08 \\
\hline 15 & 18.6 & 1.0 & 38.4 & 22.3 & 63 & 23 & 8.7 & 10.3 & 4.6 & 45 & 18 & 07 \\
\hline 16 & 4.2 & 1.0 & 39.3 & 24.0 & 64 & 24 & 9.0 & 10.7 & 6.0 & 26 & 09 & 03 \\
\hline 17 & 0.6 & 0.0 & 39.4 & 21.6 & 55 & 19 & 10.5 & 10.6 & 5.2 & 30 & 20 & 12 \\
\hline 18 & 15.2 & 2.0 & 40.5 & 22.8 & 57 & 20 & 10.8 & 10.9 & 6.2 & 22 & 19 & 06 \\
\hline 19 & 0.5 & 0.0 & 41.2 & 24.4 & 42 & 16 & 11.7 & 9.5 & 6.7 & 32 & 21 & 13 \\
\hline 20 & 0.0 & 0.0 & 42.0 & 26.7 & 45 & 17 & 12.4 & 8.2 & 6.3 & 35 & 24 & 18 \\
\hline 21 & 0.7 & 0.0 & 40.7 & 27.0 & 55 & 24 & 12.0 & 10.6 & 8.5 & 30 & 25 & 20 \\
\hline 22 & 3.0 & 1.0 & 41.3 & 26.9 & 56 & 25 & 12.3 & 9.2 & 7.6 & 28 & 23 & 19 \\
\hline
\end{tabular}


Table.2 Simple correlation and regression of weather parameter with pest of Okra

\begin{tabular}{|c|c|c|c|c|c|c|c|c|c|}
\hline \multirow[t]{2}{*}{ Parameter } & \multicolumn{3}{|c|}{ Earias vitella } & \multicolumn{3}{|c|}{ Whitefly } & \multicolumn{3}{|c|}{ Jassids } \\
\hline & Intercept (a) & Slope (b) & 'r' value & Intercept (a) & Slope (b) & 'r' value & Intercept (a) & Slope (b) & 'r' value \\
\hline $\mathbf{R F}$ & 20.13 & 0.9224 & 0.383 & 15.07 & 0.2220 & 0.155 & 9.017 & -0.1182 & -0.109 \\
\hline RD & 21.07 & 5.375 & 0.237 & 15.95 & 1.750 & 0.131 & 8.812 & -0.4375 & -0.043 \\
\hline $\mathbf{T}_{\max }$ & -11.51 & 3.594 & $0.753 * *$ & -79.17 & 2.472 & $0.880 * *$ & -55.78 & 1.679 & $0.780 * *$ \\
\hline $\mathbf{T}_{\min }$ & -24.69 & 2.260 & $0.689 * *$ & -10.03 & 1.225 & $0.634 * *$ & -16.16 & 1.180 & $0.717 * *$ \\
\hline RH-I & 77.60 & -0.9194 & $-0.673 * *$ & 52.45 & -0.6167 & $-0.767 * *$ & 33.32 & -0.4141 & $-0.672 * *$ \\
\hline RH-II & 45.55 & -1.060 & $-0.499 * *$ & 34.32 & -0.8684 & $-0.695 * *$ & 14.92 & -0.292 & 0.305 \\
\hline EVP & -19.88 & 4.564 & $0.707 * *$ & -14.42 & 3.219 & $0.847 * *$ & -15.99 & 2.632 & $0.904 * *$ \\
\hline BSS & 8.843 & 1.385 & 0.086 & 3.875 & 1.171 & 0.123 & 29.16 & -2.024 & -0.277 \\
\hline \multirow[t]{2}{*}{ WV } & -6.851 & 5.384 & $0.543 *$ & -2.930 & 3.381 & $0.579 *$ & -10.69 & 3.507 & $0.784 * *$ \\
\hline & & & & & & & & & $\mathrm{N}=15$ \\
\hline
\end{tabular}


Simple correlation and regression between weather parameters and Jassid on okra

The data on correlation coefficient showed that the correlation of jassid with weather parameters $\mathrm{T}_{\max }\left(\mathrm{r}=0.780^{* *}\right), \mathrm{T}_{\min }(\mathrm{r}=$ $0.717 * *), \operatorname{EVP}(0.904 * *)$ and $\mathrm{WV}(0.784 * *)$ were positively significant and RH-I was negatively significant but BSS and RF were non significant.

The regression equations on okra were $\mathrm{Y}=$ $33.32-0.4141 \mathrm{x}$ which indicated that for every unit increase in morning relative humidity decreased Jassid attack by 0.4141 . Also $\mathrm{Y}=-55.78+1.679 \mathrm{x}, \mathrm{Y}=-16.16+$ $1.180 x, Y=-15.99+2.632 x, Y=-10.69+$ $3.507 \mathrm{x}$ which indicated that every unit increased in $\mathrm{T}_{\max }, \mathrm{T}_{\min }, \mathrm{EVP}$ and $\mathrm{WV}$ increased incidence of jassid by $1.679,1.180$, 2.632 and 3.507 respectively. Similar result were reported by Patel et al., (1997) that significant positive relationship was observed among Amrasca biguttulla population level and maximum temperature $(\mathrm{r}=0.82)$ as well as hours of bright sunshine $(\mathrm{r}=0.82)$. The population of Amrasca biguttulla was increased during monsoon when temperature remained around $37.0^{\circ} \mathrm{C}$ along with at least 10 hours of bright sunshine.

\section{Simple correlation and regression between weather parameters and Jassid on okra}

The data on correlation coefficient showed that the correlation of jassid with weather parameters $\mathrm{T}_{\max }\left(\mathrm{r}=0.780^{* *}\right), \mathrm{T}_{\min }(\mathrm{r}=$ $\left.0.717^{* *}\right)$, EVP $(0.904 * *)$ and $\mathrm{WV}\left(0.784^{* *}\right)$ were positively significant and RH-I was negatively significant but BSS and RF were non significant.

The regression equations on okra were $\mathrm{Y}=$ $33.32-0.4141 \mathrm{x}$ which indicated that for every unit increase in morning relative humidity decreased Jassid attack by 0.4141 .
Also $\mathrm{Y}=-55.78+1.679 \mathrm{x}, \mathrm{Y}=-16.16+$ $1.180 x, Y=-15.99+2.632 x, Y=-10.69+$ $3.507 \mathrm{x}$ which indicated that every unit increased in $\mathrm{T}_{\max }, \mathrm{T}_{\min }, \mathrm{EVP}$ and $\mathrm{WV}$ increased incidence of jassid by $1.679,1.180$, 2.632 and 3.507 respectively. Similar result were reported by Patel et al. (1997) that significant positive relationship was observed among Amrasca biguttulla population level and maximum temperature $(\mathrm{r}=0.82)$ as well as hours of bright sunshine $(\mathrm{r}=0.82)$. The population of Amrasca biguttulla was increased during monsoon when temperature remained around $37.0^{\circ} \mathrm{C}$ along with at least 10 hours of bright sunshine.

\section{References}

Anonymous. (2011). Economic survey of Indi a (2010-11) www.India.org.in.

Balasubramanian, G, Balasubramanian, M. and Khulandikula, R. 1982. Seasonal incidence of bollworms on cotton. Madras Agril. J., 69: 124-125

Brar, K.S.; Arora, S.K. and Ghai, T.R. (1994). Losses in fruit yield of okra due to Earias spp. as influenced by dates of sowing and varieties. J. Insect. Sci., 7(2): 133-135.

Daware, D.G., Kurtadikar, J.S., Lavekar, R.C. and Bhosale, B.B. (2003). Achievement in insect pests management in cotton. Research highlight for 1972-2002. Department of Entomology, Marathwada Krishi Vidhyapeeth, Parbhani, Pp. 4-6.

Dhaka, S.R. and Pareek, B.L. (2008). Weather factors influencing population dynamics of major insect pests of cotton under semi arid agro system, Indian J. Ento., 70 (2):157-163.

Dhamdhere, S.V.; Bahadar, J. and Misra, U.S (1985). Studies on occurrence and succession of pest of okra. Indian $J$. Pl. Prot. 12(1): 9-12.

Gupta S.C. Prasad, G.S., Surface, A and 
Ahemad, S. (1998). Weather factors and incidence of Earias vittella fab in okra (Abelmoschus esculentus L. Moench) J. Res. Birsa Agril Univ. 10 (1): 12-15.

Hegde, M., Nidagundi, J.M., Biradar, D.P., Udikeri, S.S. and Khadi, B.M. (2004). Performance of $\mathrm{Bt}$ and non $\mathrm{Bt}$ cotton hybrids against insect pests under irrigated condition. International symposium on "Strategies for Sustainable Cotton Production - A Global Vision - 3" An In House $J$. Agric. Finance - Op Ltd., 135-138, Ltd., 143-143.

Krishnaih, K. 1980. Methodology for assessing crop losses due to pest of vegetables, In Assessment of crop losses due to pests and disease, UAS Bangalore, India. Eds H.C. Govinda G.K. Veeresh P.T. Walker and J.H.
Jakun. proceeding of the workshop held from September 19-30 1977 at University of Agril. Sci. Baglore, India, pp. 259-267.

Mohapatra, L.N. (2008). Population dynamics of sucking pests in hirsutum cotton and influence of weather parameters on its incidence in western Orissa. $J$. Cotton Res. Dev., 22 (2): 192-194.

Patel, K. L., Patel, J. R., Jayani, D. B., Shekh, A. M. and Patel, N. C. (1997). Effect of seasonal weather on incidence and development of Major Pest of okra. (Abelmoschus esculentus L.). J. Agric. Sci., 67 (5): 181-183.

Rawat, R.R. and Sahu, H.R. (1973). Efficacy of some new insecticides for the control of okra shoot and fruit borer, Earias vittella (F.). Guj. agric. Univ. Res. J., 15(1): 99-100.

\section{How to cite this article:}

Burade, D.D. A.M. Khobragade and Shinde, P.B. 2019. Influence of Weather Parameters on Pest of Okra in Parbhani Kranti Variety. Int.J.Curr.Microbiol.App.Sci. 8(01): 806-812. doi: https://doi.org/10.20546/ijcmas.2019.801.088 